\title{
Interaksi Simbolik dalam Perencanaan Komunikasi Pemasaran (Studi Kasus Brand Cocopi)
}

\author{
Arnelia Lie, Muhammad Adi Pribadi \\ arnelialie@gmail.com,adip@fikom.untar.ac.id
}

Fakultas Ilmu Komunikasi Universitas Tarumanagara

\begin{abstract}
Abstarct
A marketing communication aims to introduce a product, field or service in order to increase sales. Cocopi is one of the beverage businesses that has been located in various places in Jakarta, especially in Muara Karang Pluit. Cocopi is loved by many people from offices, school children to the elderly, so Cocopi is active in the Go-Food application. At the time of covid-19, managing a business is very difficult because of the many obstacles faced. So many things that must be re-planned and changed to keep employees and Cocopi customer healthy and safe, then a lot of experience that can be taken in this situation and condition at the time of covid-19. And one way to survive during covid-19 used by Cocopi is to promote through Go-Food, so that it is safe for everyone and still runs according to the rules. This research uses qualitative methodology with case study strategy. This data collection method with indepth interviews by Cocopi Manager as well as documentation, non-participant observations, the conclusion of this research is an interaction process that has meaning or symbol in daily activities in Cocopi Muara Karang Pluit.
\end{abstract}

Keywords: case studies, cocopi, marketing communication, symbolic interactionism

\begin{abstract}
Abstrak
Sebuah komunikasi pemasaran bertujuan untuk memperkenalkan suatu produk, bidang atau jasa agar penjualan meningkat. Cocopi merupakan salah satu usaha minuman yang telah berada di berbagai tempat di Jakarta, terutama di Muara Karang Pluit. Cocopi di gemari banyak orang baik perkantoran, anak-anak sekolah sampai lansia, sehingga Cocopi aktif dalam aplikasi Go-Food. Pada saat pandemi covid-19 melanda, mengelola bisnis sangatlah sulit karena banyak sekali kendala yang dihadapi. Begitu banyak hal yang harus direncanakan ulang dan diubah agar karyawan dan pelanggan Cocopi tetap sehat dan aman. Banyak sekali pengalaman yang bisa diambil dalam situasi dan kondisi pada saat pandemi ini. Salah satu cara yang digunakan Cocopi agar tetap survive selama covid-19 adalah mempromosikan produknya lewat Go-Food, Penelitian ini menggunakan metodologi kualitatif dengan strategi studi kasus. Metode pengumpulan data dilakukan dengan wawancara mendalam bersama manager Cocopi, pemeriksaan dokumentasi, dan observasi non-partisipan, Kesimpulan penelitian ini adalah proses interaksi yang mempunyai makna atau simbol dalam kegiatan sehari-hari di Cocopi Muara Karang Pluit.
\end{abstract}

Kata Kunci: cocopi, interaksi simbolik, komunikasi pemasaran, studi kasus

\section{Pendahuluan}

Komunikasi pada saat ini telah melewati batasan geografis sehingga seluruh titik yang ada di dunia saling terhubung. Revolusi dalam teknologi juga telah membawa perubahan besar dalam berbagai hal, terutama pemasaran. Di masa lalu pemasaran dan promosi berjalan sendiri-sendiri, sekarang semakin banyak perusahaan 
baik berskala besar dan kecil pun menyatukan pemasaran dan promosi ke dalam sebuah aplikasi.

Cocopi merupakan sebuah produk brand minuman yang ada di Jakarta Utara, dengan bernuansa tropikal sehingga Brand ini muncul menyusul maraknya minuman dengan menggunakan bubble dan cheese cream. Penulusan Brand Cocopi dengan huruf $\mathrm{O}$ di akhir brand diganti dengan gambar biji kopi dan daun pohon kelapa di bagian atas huruf, shingga langsung tercermin minuman kopi dan minuman tropikal yang terkesan segar.

Dalam komunikasi pemasaran, Cocopi memiliki strategi tersendiri dikarenakan banyak minuman dan kopi susu kekinian yang sepi pengunjung bahkan banyak mitra yang dirugikan, karena terlalu banyak brand yang konsepnya mirip, dengan menu serupa sehingga pelanggan tidak mempunyai loyalitas.

Cocopi juga tersedia di Go-Food dan Grab Food untuk memudahkan para pembeli yang tidak bisa datang langsung ke lokasi. Dan dengan adanya penelitian ini peneliti ingin mengetahui perencanaan komunikasi pemasaran Cocopi. Dan peneliti ingin mengetahui proses interaksi simbolik dalam komunikasi pemasaran di Cocopi, yang mampu bersaing dengan gerai kopi lainnya.

Hal ini merupakan bentuk strategis pemasaran yang dijalankan Cocopi melalui aplikasi Go-Food dan Instagram agar semakin banyak lagi masyarakat yang dapat mengetahui Cocopi. Dengan adanya Go-Food dan instagram juga dapat diketahui seberapa banyak masyarakat yang ingin mencobai produk-produk minuman Cocopi.

Dan dengan adanya penelitian ini, peneliti akan mencari tahu bagaimana proses interaksi simbolik dalam perencanaan komunikasi pemasaran di Cocopi yang mampu bersaing dengan gerai-gerai kopi lain yang sudah ada terlebih dahulu di bandingkan dengan Cocopi dan membuka banyak cabang di setiap kota-kota besar yang ada di Indonesia.

Dalam teori interaksi simbolik diyakinkan bahwa individu dapat membentuk makna melalui proses komunikasi. Pada saat makna tersebut telah terbentuk, tentunya membuat kesalahpahaman menjadi dapat diatasi.

Komunikasi Pemasaran adalah proses bagaimana saling menguntungkan antara penjual dan pembeli. Dua sasaran pemasaran adalah menarik individu agar dapat menjadi pelanggan dengan menjanjikan dari keunggulan produk, serta menjaga pelanggan yang sudah ada dengan terus memberikan yang terbaik untuk pelanggan tersebut.

Menurut Larry Percy (2012) komunikasi dapat membangun hubungan untuk saling menguntungkan. Komunikasi pemasaran akan lebih baik apabila dilakukan berasarkan perencanaan yang tepat langsung ke sasaran.

\section{Metode Penelitian}

Dalam penelitian ini penulis menggunakan metode penelitian kualitatif. Penelitian kualitatif dapat di definisikan bahwa penelitian kualitatif adalah sebuah penelitian yang bertujuan untuk lebih mengerti fenomena yang dialami oleh subjek penelitian yang di dalamnya terdapat melibatkan perilaku, persepsi, motivasi, tindakan dan setelah itu di deskripsikan dalam bentuk kata-kata pada konteks tertentu dengan menggunakan metode alamiah.

Dalam penelitian studi kasus terdapat tiga tipe yaitu studi kasus eksplanatoris, eksploratoris, dan deskriptif. Studi kasus yang digunakan oleh penulis adalah eksploratoris. Secara umum, studi kasus sangatlah cocok apabila dikaitkan dengan 
penelitian dengan pertanyaan bersifat how atau why. Dalam praktiknya peneliti studi kasus perlu lebih lagi memusatkan perhatiannya pada perancangan dan penyelenggaraan agar dapat menangani kritik-kritik tertentu terhadap tipe pilihannya (Yin, 2014).

Beberapa komponen rencangan penelitian yang juga sangat penting adalah pertanyaan penelitian, pertanyaan akan bervariasi tetapi lebih disarankan berbentuk "siapa", "apa", "dimana", "bagaimana", dan "mengapa". Strategi studi kasus lebih cocok untuk pertanyaan dengan "bagaimana" dan "mengapa" (Yin, 2014).

Subjek dalam penelitian ini adalah narasumber atau informan yang dapat memberikan informasi terhadap masalah yang diteliti oleh peneliti. Subjek tersebut dapat berupa sebagai individu, komunitas, dan organisasi yang di dalam dirinya melekat objek penelitian ini. Narasumber atau informan tersebut harus memberikan informasi yang jelas dan akurat kepada peneliti agar peneliti dapat menemukan hasil penelitian yang dicari.

Desain penelitian diperlukan dalam pendekatan umum studi kasus. Penelitian ini menggunakan metode pengumpulan data non partisipan, wawancara mendalam, serta dokumentasi dan dokumen arsip. Teknik ini dilakukan untuk menjadi penguat atau membuktikan bahwa penelitian ini benar-benar merupakan penelitian ilmiah juga untuk menguji data yang sudah diperoleh agar data tersebut dalam penelitian kualitatif dapat dipertanggungjawabkan.

Penulis melakukan wawancara dengan para informan untuk pengumpulan datanya. Kemudian penulis akan membuat penafsiran atas data yang diperoleh dari hasil wawancara. Hasil penafsiran peneliti nantinya akan dikembalikan lagi kepada informan untuk memastikan penafsiran ini benar adanya sesuai dengan pengalaman para informan.

\section{Hasil Temuan dan Diskusi}

Cocopi merupakan jenis usaha franchise yang memiliki keunikan tersendiri dalam menghadirkan menu-menunya, hal tersebut dapat dilihat dari nama-nama di dalam buku menu nya. Dan lagi Cocopi akan merilis menu-menu baru setelah keadaan kondusif, terdapat makanan santai dan juga makanan berat, hal ini tergantung dari kebijakan masing-masing pemilik setiap cabang Cocopi.

Dalam memasarkan produknya, Cocopi menerapkan startegi berupa promo menarik di Gofood dengan potongan harga yang cukup fantastis dan juga menampilkan menu-menu atau varian-varian baru yang lebih kreatif dan unik dan mengiklankan produknya lewat Instagram sebagai sarana pemasaran.

Berdasarkan data yang telah diperoleh saat penyelesaian tugas akhir ini Cocopi menjadi bagian dari konsep generalized others yang dijelaskan oleh Mead. Sebagaimana diberlakukannya peraturan baru (PSBB) dari pemerintah yang membuat Cocopi harus mengikuti aturan tersebut untuk menrkan rantai penyebaran covid-19.

Pembahasan ini berdasarkan wawancara mendalam yang penulis lakukan dengan Cocopi cabang Muara Karang Pluit. Wawancara ini menggali memnhenao teamwork pada proses pembentukan perencanaan komunikasi pemasaran yang disambungkan dengan teori terkait dalam penelitian yaklni teori interaksi simbolik dan komunikasi pemasaran. 


\section{Pemilihan Merek dan Peninjauan}

Sebelum menjalankan bisnis ini, tentu pemilik terlebih dahulu mencari tahu bagaimana bisnis yang sedang booming saat ini. Banyak sekali pertimbangan serta melalui proses yang detail sampai akhirnya owner memutuskan untuk membuka usaha di bidang coffee shop. Setelah memilih usaha itu tentu pemilik mempelajari terlebih dahulu mengenai kopi dan minuman tropikal lainnya, terutama dari segi keunikan rasa karena di racik sendiri oleh pemilik bahan-bahan yang digunakan untuk membuat minuman.

Menurut penjelasan dari informan, bahwa dalam menjalankan bisnis ini beliau juga harus mempelajari bagaimana produk nya serta variasi di dalam produk nya. Dan juga menurut informan bahwa Cocopi memiliki varian rasa yang menarik dan banyak sehingga melekat di masyarakat.

Dalam hal ini sudah sangat jelas dapat disimpulkan bahwa seperti yang telah dijelaskan oleh Mead, bahwa dalam teori interaksi simbolik dalam diri individu dapat terbentuk makna melalui proses komunikasi. Pada saat makna tersebut telah terbentuk tentunya proses komunikasi akan berjalan dengan sangat baik.

\section{Peraturan}

Peraturan dibuat untuk di taati agar suatu rencana dapat dijalankan dengan baik, hal ini merupakan sebuah landasan dalam melakukan suatu hal yang bisa kita temui di kehidupan sehari-hari, dalam hal ini penulis temukan di lingkungan Cocopi. Peraturan yang dibuat untuk menciptakan lingkungan kerja yang aman dan nyaman antara para pekerja dengan kostumer. Setiap perusahaan memiliki dan membuat aturannya sendiri dan dari setiap aturan tersebut pasti juga ada sanksi bagi siapa yang melanggar, hal ini dapat di temui di lingkungan kerja Cocopi.

Hal ini mempunyai arti yang sama dengan apa yang telah dipaparkan oleh Mead mengenai hubungan antara individu dan masyarakat. Dimana hal tersebut memaparkan tentang bagaimana kaitan antara kebebasan individu dan batasan sosial. Dari hal ini dapat disimpulkan bahwa pada interaksi simbolik makna memiliki peran yang penting untuk perilaku manusia.

\section{Tujuan Bisnis}

Dalam pembahasan ini yang di artikan dalam Tujuan Bisnis Cocopi yaitu untuk meningkatkan Brand Awareness di masyarakat atau pelanggan sekitar karena target market utama kami adalah orang perkantoran dan anak-anak sekolah. Karena produk yang diciptakan Cocopi dapat diminum semua umur.

Dalam pembahasan ini dapat dikaitkan dengan generalized others yang dimana bisnis memiliki aturan-aturan dan peranan sehingga visi dan misi perusahaan selaras dengan nilai dan konsep perusahaan.

\section{Strategi Pemasaran}

Pemasaran secara luas adalah proses sosial yang artinya penjual mendapatkan apa yang mereka butuhkan melalui pertukaran nilai dengan orang lain. karena itu pemasaran dapat di definisikan sebagai bentuk proses dimana perusahaan menciptakan nilai yang baik untuk pelanggan serta menciptakan adanya hubungan baik jangka panjang dengan pelanggan yang bertujuan mendapatkan nilai yang baik dari pelanggan sebagai bentuk apresiasi untuk perusahaan tersebut.

Setiap perusahaan tentu mempunyai faktor-faktor kesulitan dalam menjalankan bisnis dan promosinya. Place merupakan komponen terpenting dalam 
pemasaran seperti yang telah disampaikan oleh informan bahwa konsumen yang akan membeli Cocopi secara online pasti akan memilih cabang dengan radius terdekat dengan posisinya. Hal ini merupakan bagian terpenting yang harus diperhatikan dalam membuka usaha.

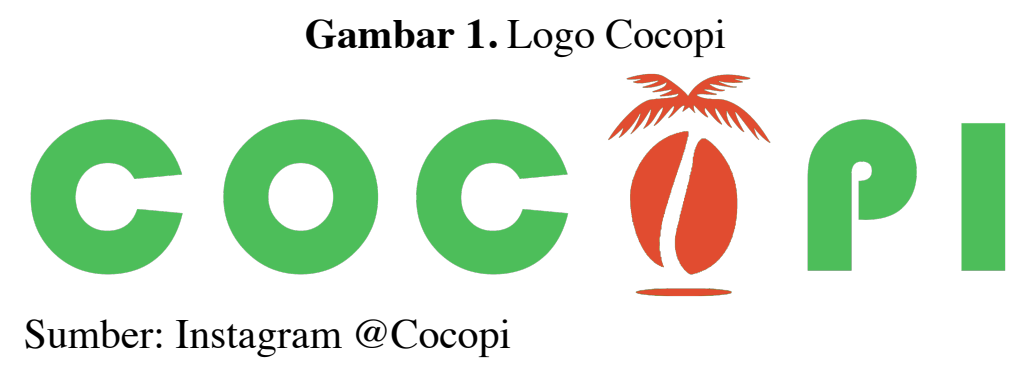

Gambar 2. Struktur Organisasi Cocopi Muara Karang Pluit

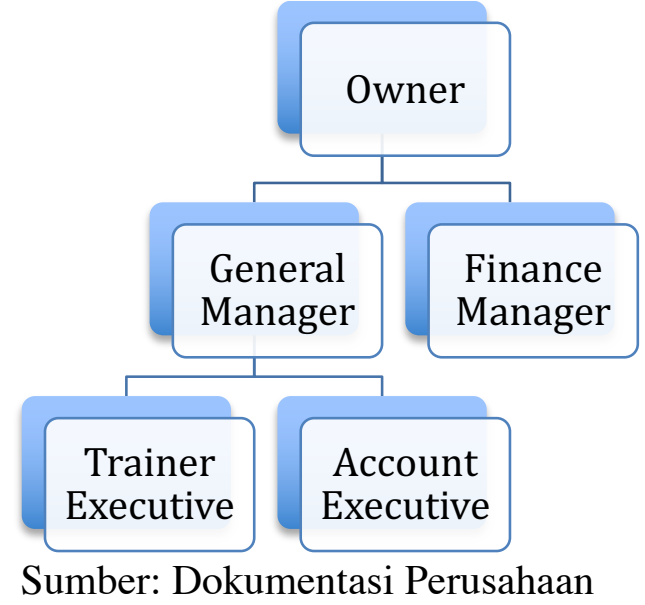

Perbedaan Cocopi dengan merek lainnya adalah karena Cocopi berbasis minuman tropikal yang di padu dengan kopi, dan bahan-bahan dari Cocopi ini diracik sendiri oleh owner sehingga menciptakan rasa yang segar dan tak terlupakan oleh masyarakat.

\section{Kesimpulan}

Berdasarkan hasil penjelasan diatas, kesimpulan dalam penelitian ini adalah sebagai berikut:

1. Cocopi memiliki konsep yang sejalan dengan generalized others dalam menjalankan usahanya.

2. Dalam Perencanaan Komunikasi Pemasaran di Cocopi muara Karang Pluit terdapat beberapa hal yang harus diperhatikan antara lain:pemilihan merek dan peninjauan, peraturan, promosi dan startegi pemasaran.

3. Interaksi Simbolik yang terjadi pada Cocopi Muara Karang Pluit sangat mempunyai peran penting dalam kegiatan sehari-hari di gerai tersebut.

\section{Ucapan Terima Kasih}

Penelitian ini dapat diselesaikan karena mendapatkan bantuan serta dukungan dari banyak pihak. Oleh karena itu, penulis mengucapkan banyak terima kasih yang 
sebesar-besarnya kepada Leonardo Haryanto selaku manager dari Cocopi Muara Karang Pluit atas ketersedia nya dalam membantu penulis untuk menyelesaikan penelitian ini, juga penulis sampaikan ucapan terima kasih untuk semua informan yang terlibat dalam penelitian ini.

\section{Daftar Pustaka}

Percy, Larry., \& Rossiter, John. (2012). Strategic Advertising Management. Oxford University Press: New York.

Yin, Robert, K. (2014). Studi Kasus: Desain \& Metode. Jakarta: Rajagrafindo Persada. 